\title{
Precision viticulture in Brazil: Current research status on wine grape
}

\author{
Alberto Miele ${ }^{1, a}$, Carlos Alberto Flores ${ }^{2}$, and José Maria Filippini Alba ${ }^{2}$ \\ ${ }^{1}$ Embrapa Uva e Vinho, 95700-000 Bento Gonçalves, RS, Brazil \\ ${ }^{2}$ Embrapa Clima Temperado, 96010-971 Pelotas, RS, Brazil
}

\begin{abstract}
Technologies associated to precision viticulture (PV) are not currently used by Brazilian growers. To overcome this situation, a research is being carried out since 2011 in a vineyard of Merlot using a wide range of PV technologies. During this period, several PV research activities were performed which will be concluded in a couple of years. Therefore, final results depend on further variable evaluation which should be done by means of geostatistic, Geographic Information Systems and Principal Component Analysis. This paper briefly presents a series of methodological procedures used in different ways to attain the objective of this research project. In the sequence, it describes one final result and nine partial ones. Morphological and physicochemical analyses of soil showed that the vineyards are established on three taxonomic classes of soil - Argissolo, Cambissolo and Neossolo -, which are formed by ten mapping units. The partial results are mainly related to the utilization of GIS, modeling and must and wine composition of five mapping units; however they show results of only one year. With the complete set of analyses, data should be spatialized and maps prepared. Then, it will be possible to recommend different practices to each soil type and to aid oenologists to direct wines to a specific quality pattern.
\end{abstract}

\section{Introduction}

Production and commercialization of Brazilian wines have a strong competition of wines mainly coming from South American and European countries. To mitigate this situation, wine institutions and the wine industry improved some actions in different areas, such as the adoption of recent viticultural and oenological technologies.

Among the viticultural technologies, there is a concern related to soil managing. In Serra Gaúcha, the southern and most important Brazilian viticultural region, the soil presents structure, texture and physicochemical composition that vary even in small areas. This soil spatial variability, in addition to a temporal variability, can have effect on vineyard yield and wine composition and quality, a topic related to precision agriculture (PA). PA has some definitions, a single one defines it as the managing of a crop in an area with spatial and temporal scale smaller than the entire area of this crop [1]. The utilization of technologies in PA is relatively new in vineyards, and then called precision viticulture (PV), where the pioneer works were carried out in the United States [2] and Australia [3].

However, research on PA in Brazil only began in 2010, by Embrapa researchers who carried out works related to the project "Precision Agriculture for the Sustainability of Agricultural Production System in Brazilian Agribusiness". As a component of this project, field works concerning research in viticulture and oenology has already finished. However, there are still some laboratory analyses to be done. Later, data of

\footnotetext{
${ }^{a}$ Corresponding author: alberto.miele@embrapa.br
}

four years will be analyzed using geostatistic, Geographic Information Systems and multivariate analyses.

In this way, this paper presents final results of the soil types where vineyards are established and partial results concerning different topics related to grape and wine.

\section{Material and methods}

Field works in PV are being carried out in three vineyards of Merlot, clone 347, where grapevines were grafted on the 1103 Paulsen rootstock. Two vineyards were established in 2005 and one in 2006, all vertical trellised, cordon trained and spur pruned. These vineyards have a global area of 2.42 ha where 11,829 grapevines are cultivated. They are established in Vale dos Vinhedos (DO Vale dos Vinhedos), Serra Gaúcha, RS, the most important Brazilian viticultural region. Vineyard cultural practices were performed according to the owner, being similar for the three vineyards.

Many procedures related to PA were used in the works carried out since the beginning of this research, which are now briefly described:

\subsection{Grapevines and vineyards georeferencig}

The work was carried out in three vineyards, namely vineyards 1, 2 and 3. In each one, the coordinates latitude, longitude and altitude were established by means of a Sokkia SET 610 total station and a geodesic GPS Sokkia GSR 2600. Data of these measures were used to prepare maps concerning altitude, declivity and grid $(10 \mathrm{~m} \times 10 \mathrm{~m})$ which were used to mapping the soils. 


\subsection{Morphological and physicochemical characterization of soils}

The soil morphological characterization was done in 2011 by studying its profile and physicochemical analyses. In each profile, soil samples were collected in four depths, i.e., 0-14, 14-35, 35-70/80 and 70/80-150 cm. The evaluated variables were a) fractions of total sample; b) granulometric composition of fine land; c) clay dispersed in water; d) flocculation degree; e) silt/sand ratio; f) $\mathrm{pH}$ in $\mathrm{H}_{2} \mathrm{O}$ and $\left.\mathrm{KCl} ; \mathrm{g}\right)$ sorption complex $\left(\mathrm{Ca}^{2+}, \mathrm{Mg}^{2+}\right.$, $\left.\mathrm{K}^{+}, \mathrm{Na}^{+}, \mathrm{S}, \mathrm{Al}^{3+}, \mathrm{H}^{+}, \mathrm{T}\right)$; h) $\mathrm{V}$; i) $100 \mathrm{Al}^{3+} / \mathrm{S}+\mathrm{Al}^{3+}$; j) bioavailable $\mathrm{P}$; k) organic $\mathrm{C}$; 1) $\mathrm{N}$; m) $\mathrm{C} / \mathrm{N}$ ratio; n) $\mathrm{H}_{2} \mathrm{SO}_{4}$ attack $\left(\mathrm{SiO}_{2}, \mathrm{Al}_{2} \mathrm{O}_{3}, \mathrm{Fe}_{2} \mathrm{O}_{3}, \mathrm{TiO}_{2}, \mathrm{P}_{2} \mathrm{O}_{5}, \mathrm{MnO}\right.$, $\mathrm{Ki}, \mathrm{Kr}, \mathrm{Al}_{2} \mathrm{O}_{3} / \mathrm{Fe}_{2} \mathrm{O}_{3}$; o) apparent electric conductivity; p) nutrients ( $\mathrm{S}, \mathrm{Zn}, \mathrm{Cu}, \mathrm{B}, \mathrm{Mn})$.

Maps were made establishing the vineyard coordinates - latitude, longitude and altitude. This was done using a total station and a geodesic GPS (grid $10 \mathrm{~m} \times 10 \mathrm{~m}$ ) which still permitted to prepare maps of declivity (scale of 1:500).

Besides the morphological studies, 124 samples of A and B horizons were collected to determine its fertility (grid $20 \mathrm{~m} \times 20 \mathrm{~m}$ ). The analyzed variables were: a) granulometric composition (pebbles, gravel, coarse sand, fine sand, silt and full clay); b) clay dispersed in water; c) flocculation degree; d) silt/clay ratio; e) organic $\mathrm{C}$; f) $\mathrm{C} / \mathrm{N}$ ratio; g) $\mathrm{H}+\mathrm{Al}$; h) basic soil analysis (bioavailable $\mathrm{P}, \mathrm{pH}$ in $\mathrm{H}_{2} \mathrm{O}$ and $\mathrm{KCl}, \mathrm{N}, \mathrm{Ca}, \mathrm{Mg}, \mathrm{K}, \mathrm{Na}, \mathrm{S}, \mathrm{T}$ and $\mathrm{V}$ values and $\mathrm{Al}$ saturation; i) nutrients (Fe, Mn, Zn, B, Al, Na, S).

\subsection{Soil apparent electrical conductivity (ECa)}

The apparent soil electrical conductivity was measured in 2011 with a sensor adapted to the soil conditions of the vineyards. Measures were made with the sensor placed between grapevine rows, near the 248 georeferenced grapevines. So, each measure had the apparent electrical conductivity value and coordinates of each plant - latitude, longitude and altitude.

\subsection{Chlorophyll index}

The chlorophyll index was determined during veraison of 2011, in 10 leaves/georeferenced grapevine, i.e., it was measured in 2,480 grapevine blades. An electronic apparatus Falker ClorofiLOG CFL 1030 was used, where chlorophyll $a$ and $b$, chlorophyll $a+b$ and chlorophyll $a / b$ ratio were considered.

\subsection{Normalized Difference Vegetation Index (NDVI)}

The NDVI was determined during the veraison of 2011 and 2013, in 6,238 points each year. Measures were performed by means of a CropCircle sensor, model CS 210, equipped with a Trimble and a Geo SCOUT GLS 400 datalog. The sensor emits lights in the red and infrared wavelengths and captures the reflectance of these wavelengths.

\subsection{Leaf mineral composition}

Leaf samples of 248 georeferenced grapevines were collected (grid $10 \mathrm{~m} \times 10 \mathrm{~m}$ ) during four years $(2011$ to
2014). Ten mature leaves/grapevine were sampled and then petioles were taken from leaf blades. In the laboratory, petioles were dried in an oven at $60^{\circ} \mathrm{C}$, ground and placed in plastic bags. Macronutrients $(\mathrm{N}, \mathrm{P}, \mathrm{K}, \mathrm{Ca}, \mathrm{Mg})$ and micronutrients $(\mathrm{Cu}, \mathrm{Zn}, \mathrm{Fe}, \mathrm{Mn}, \mathrm{Na}, \mathrm{Al})$ were analyzed.

\subsection{Crop variables}

The following variables were determined in the vineyards: number of clusters/grapevine, weight/cluster, yield/grapevine, yield/ha, pruning weight and pruning weight/fruit weight ratio.

\subsection{Physicochemical composition of must}

Grape sampling was done during four years (2011 to 2014) and consisted of 30 berries randomly collected from the 248 georeferenced grapevines. After crushing these berries, must was centrifuged and then the variables total soluble solids $\left({ }^{\circ}\right.$ Brix), titratable acidity, $\mathrm{pH}$ and ${ }^{\circ}$ Brix/titratable acidity ratio were analyzed.

\subsection{Winemaking}

Forty kilograms of grapes were sampled from each type of soil during four years (2011 to 2014), i.e., two Argissolo, one Cambissolo and two Neossolo, which means a total of $200 \mathrm{~kg}$ of grapes. They were processed and microvinifications were done in duplicate in glass recipients of $20 \mathrm{~L}$. Both fermentations, alcoholic and malolactic, were accompanied by must and wine analyses, respectively. When wines were stabilized, they were bottled and stored in a $6{ }^{\circ} \mathrm{C}$ temperature room.

\subsection{Physicochemical composition of wine}

After the end of the malolactic fermentation and wine stabilization, analyses were performed considering the following variables: density, alcohol, titratable acidity, volatile acidity, dry extract, reducing sugars, reduced dry extract, alcohol in weight/reduced dry extract ratio, ashes, alkalinity of ashes, total polyphenols index, tannins, anthocyanins, absorbances at 420, 520 and $620 \mathrm{~nm}$, color intensity, hue, ethanal, ethyl acetate, methanol, 1-propanol, 2-methyl-1-propanol, 2-methyl-1-butanol, 3-methyl-1-butanol, sum of higher alcohols and minerals (N, P, K, Ca, Mg, Na, Mn, Cu, Fe, Zn, Li, Rb).

\subsection{Sensory characteristics of wine}

Sensory analyses were performed according to international methodologies. Visual, olfactive and gustative aspects were taken into account in each sensory section: visual: limpidity, color intensity and hue; olfactive: intensity, equilibrium, quality and persistence; gustative: intensity, body, astringency, sweetness, acidity, bitterness, salty, equilibrium, quality, persistence, floral, fruity, spicy, oak and typicality.

\subsection{Statistical analysis}

Data are being submitted to geostatistic, Geographic Information Systems and multivariate procedures. 


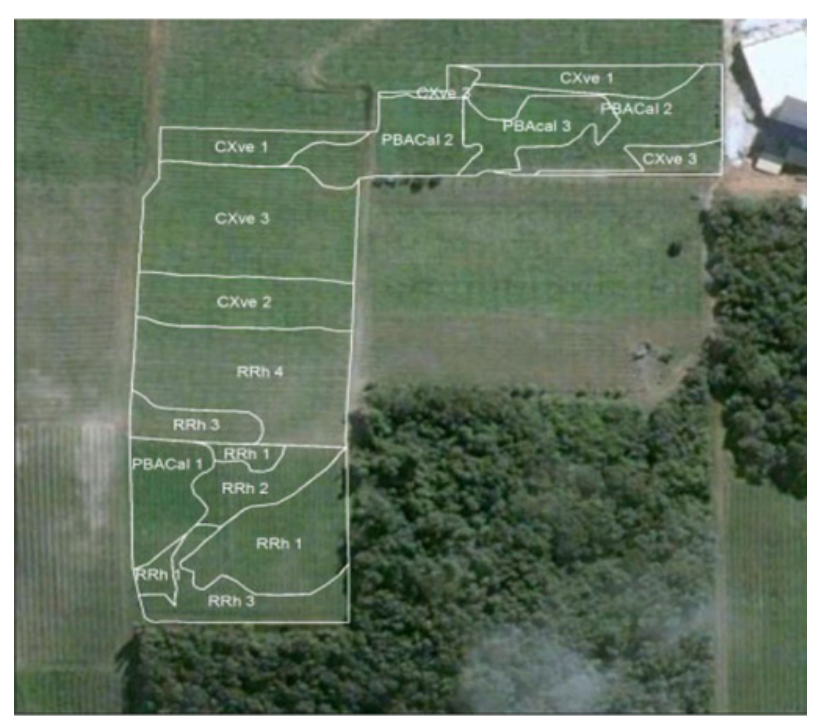

Figure 1. Vineyards map showing three taxonomic classes and 10 mapping units [4].

\section{Results}

\subsection{Soil managing zones}

Based on the vineyard and grapevine coordinates and on the morphological and physicochemical properties of soils, it was shown that there are 10 types of soils in the 2.42 ha of vineyards (Fig. 1) [4]. Indeed, there are three taxonomic classes - Argissolo, Cambissolo and Neossolo - and 10 mapping units. Argissolo (PBACal 1, 2, 3), characterized by high $\mathrm{Al}$ saturation, has three mapping units; Cambissolo (CXve 1, 2, 3), characterized by high saturation of bases, also three mapping units; and Neossolo (RRh 1, 2, 3, 4), characterized by high organic carbon, four mapping units.

\subsection{GIS in vitiviniculture}

The physicochemical parameters of horizons A and B were evaluated by means of multivariate analysis, geostatistic and Geographic Information Systems procedures. Analyses of these methods showed that there are three main groups of soils, where the edaphic attributes are almost uniform in Argissolo, Cambissolo and Neossolo (Fig. 2). Indeed, there are five mapping units in these soils. These groups were established considering the nutrient contents $\left(\mathrm{Ca}^{+2}\right.$, organic $\mathrm{C}, \mathrm{K}^{+}, \mathrm{Mg}^{+2}, \mathrm{Na}^{+}, \mathrm{N}$ and $\left.\mathrm{P}^{+5}\right)$ and $\mathrm{H}^{+}, \mathrm{T}$ and CTC values [5].

\subsection{Spatial distribution of the granulometric fractions of the vineyards}

The granulometric fractions showed similar means for clay, silt and coarse sand, which were due to the sum of the fix fractions. The chemical variables, such as $\mathrm{Al}, \mathrm{P}$ and $\mathrm{pH}$ did not show spatial variability. The other variables were adjusted to the spherical model, with different range for silt. $\mathrm{Ca}$ and $\mathrm{K}$ showed spatial association, with good spatial variability. When values were submitted to krigin, variables related to the granulometric fractions showed

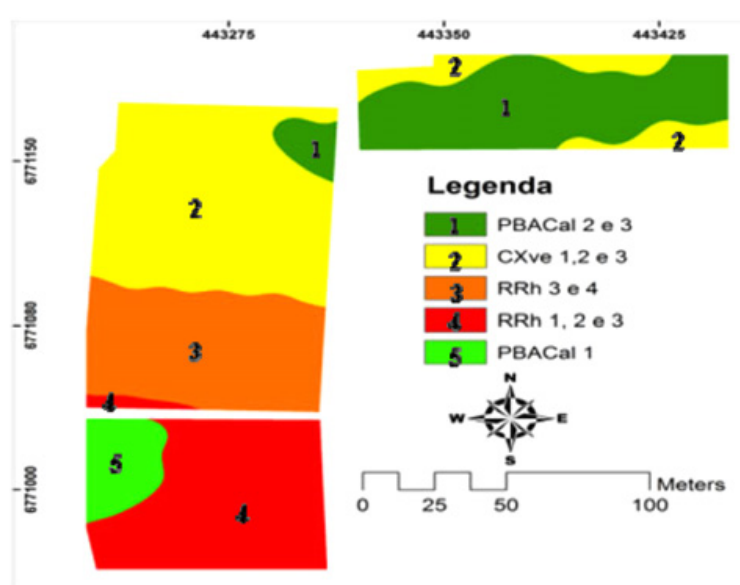

Figure 2. Scheme showing the five mapping units considered for microvinification [5].

different spatial distribution which was probably due to the altitudes of the soil [6].

\subsection{Soil taxonomic classes and spatial distribution of $\mathrm{P}, \mathrm{K}$ and $\mathrm{Ca}$}

Two taxonomic classes of soils, Cambissolo and Neossolo, are mainly present in the vineyard $n^{\circ} 2$. Results show that Cambissolo had lower $\mathrm{P}, \mathrm{K}$ and $\mathrm{Ca}$ contents than Neossolo in 2011. However, there was no difference among C, N and $\mathrm{Mg}$ contents.

Physicochemical analyses of grape musts from these two soils showed that those from Cambissolo had higher values of ${ }^{\circ} \mathrm{Brix}, \mathrm{pH}$ and ${ }^{\circ} \mathrm{Brix} /$ titratable acidity ratio, and lower of titratable acidity [7].

\subsection{Spatial modeling and precision viticulture}

Data suggest that there is a significant spatial variability in several soil attributes and a positive correlation with the taxonomic classes of soils (Argissolo, Cambissolo and Neossolo). Modeling with GIS is a potential tool for the integration information levels related to the soil properties and definition of the management zones. The "preferential" suitability class occupied about $50 \%$ of the vineyard, including almost all the Cambissolo (CXve 2 and CXve 3), and partially the Neossolo (RRh 3 and RRh 4) soils. The adjustment of the model will be necessary from the point of view of integration criteria and GIS strategy $[8,9]$.

\subsection{Soil and mineral composition of leaf petiole}

The mineral contents of the grapevine leaf petiole were analyzed in 2011 by means of the Principal Component Analysis, where the two most important components explained $72.5 \%$ of the total variation. Main results showed that $\mathrm{Ca}, \mathrm{Cu}, \mathrm{Mn}, \mathrm{Mg}$ and $\mathrm{Zn}$ were higher in Argissolo soils (PBACal 2+3); K and S, in Cambissolo (CXve 2+3); and Al, in Neossolo (RRh 1+2+3). However, the other nutrients were not discriminated [7]. 

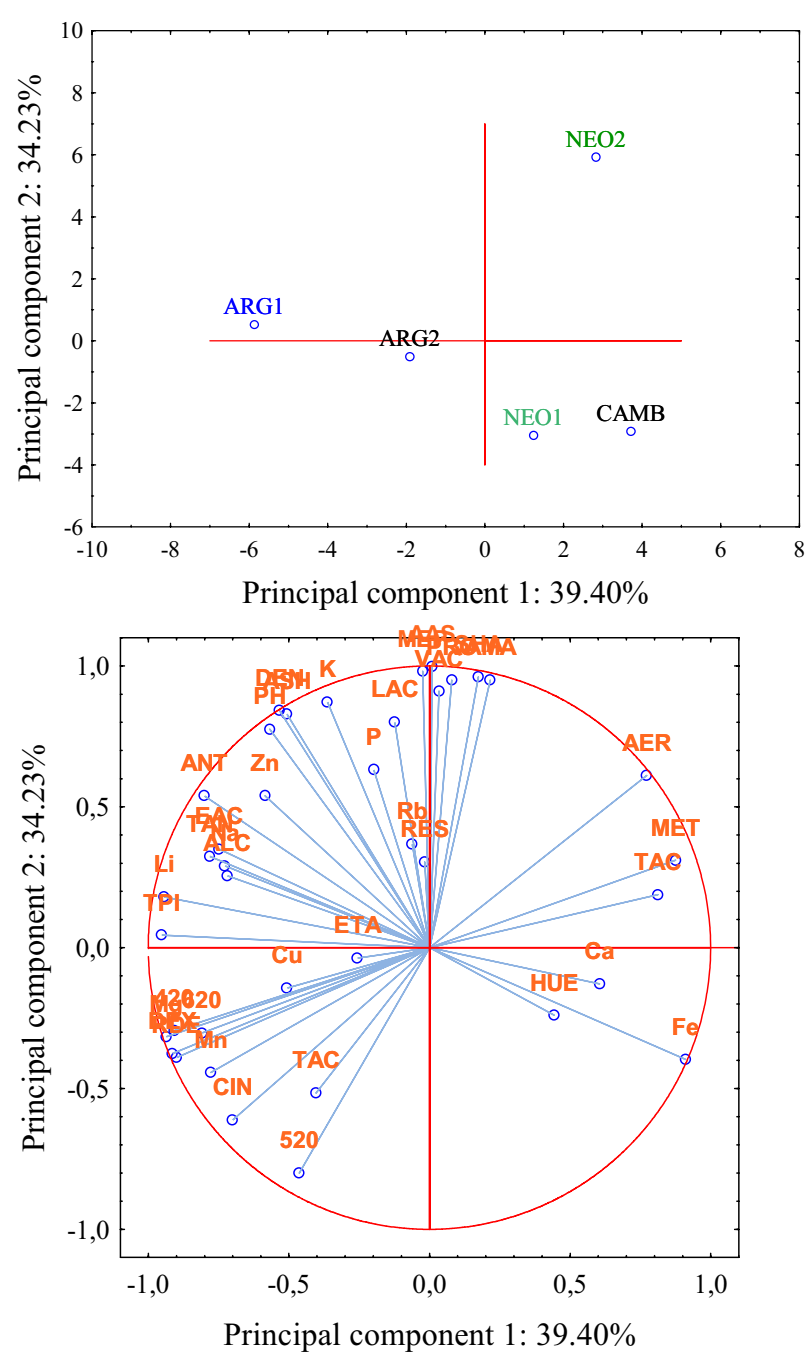

Figure 3. Projection of wines and variables on the principal components $1 \times 2$. Legend of variables: $\mathrm{DEN}=$ density, $\mathrm{PH}=\mathrm{pH}$, $\mathrm{TAC}=$ titratable acidity, $\mathrm{VAC}=$ volatile acidity, $\mathrm{ALC}=$ alcohol, $R E S=$ reducing sugars, $420=$ OD $420,520=$ OD 520, $620=$ OD $620, \mathrm{CIN}=$ color intensity, $\mathrm{HUE}=$ hue, $\mathrm{TPI}=$ total polyphenols index, $\mathrm{ANT}=$ anthocyanins, $\mathrm{DEX}=$ dry extract, $\mathrm{RDE}=$ reduced dry extract, $\mathrm{AER}=$ alcohol in weight/reducing sugars ratio, $\mathrm{ASH}=$ ashes, $\mathrm{AAS}=$ alkalinity of ashes, $\mathrm{TAN}=$ tannins, $\mathrm{TAC}=$ tartaric acid, $\mathrm{LAC}=$ lactic acid, $\mathrm{ETA}=$ ethanal, $\mathrm{EAC}=$ ethyl acetate, $\mathrm{MET}=$ methanol, $\mathrm{PRO}=1$-propanol, $\mathrm{MEP}=2$-methyl1-propanol, $\mathrm{AMA}=$ amyl alcohols, $\mathrm{SAA}=$ sum of amyl alcohols, $\mathrm{K}=$ potassium, $\mathrm{Na}=$ sodium, $\mathrm{Ca}=$ calcium, $\mathrm{Mg}=$ magnesium, $\mathrm{Mn}=$ manganese, $\mathrm{Cu}=$ copper, $\mathrm{Fe}=$ iron, $\mathrm{Zn}=$ zinc, $\mathrm{Rb}=$ rubidium, $\mathrm{Li}=$ litium, $\mathrm{P}=$ phosphorus. Legend of wines: $\mathrm{ARG1}=$ Argissolo 1, ARG2 = Argissolo 2, NEO1= Neossolo 1, NEO2= Neossolo 2, $\mathrm{CAMB}=$ Cambissolo [11].

\subsection{Soil and physicochemical composition of the must of grapes}

Principal Component Analysis showed that the two most important components explained $98.57 \%$ of the total variation. Results of the 2011 vintage show that ${ }^{\circ}$ Brix and $\mathrm{pH}$ values were more expressive in grape musts coming from Argissolo (PBACal 1, 2, 3) and Cambissolo (CXve 2, 3) but titratable acidity was higher in Neossolo (RRh1, 2, $3,4)[7]$.

\subsection{Spatial variability of Cambissolo and Neossolo soils and mineral composition}

Applying geostatistical procedures, such as kriging, results show that Cambissolo had lower values of $\mathrm{P}, \mathrm{K}$ and $\mathrm{Ca}$, but there were no differences between the two soil classes on organic $\mathrm{C}, \mathrm{N}$ and $\mathrm{Mg}$ contents. Considering the physicochemical analyses of the must from grapes cultivated on each soil class, it was shown that the must of grapes grown on Cambissolo had higher values of ${ }^{\circ} \mathrm{Brix}$, $\mathrm{pH}$ and ${ }^{\circ} \mathrm{Brix} /$ titratable acidity ratio and lower for titratable acidity [10].

\subsection{Spatial variability of soils and wine composition}

Principal Component Analysis of the 2011 vintage showed that the two most important components explained $76.63 \%$ of the total variation (Fig. 3), where PC1 discriminated wine of Argissolo (PBACal 2+3) and, with less intensity, from Cambissolo (CXve 2+3); PC2, from Neossolo 2 (RRh $1+2+3)$ and, with less intensity, from Neossolo (RRh 4) [11].

Wine from Argissolo 1 was characterized by higher values of OD 420, OD 620, color intensity, total polyphenols index, anthocyanins, tannins, dry extract, reduced dry extract, ethyl acetate, $\mathrm{Na}, \mathrm{Mg}, \mathrm{Mn}$ and $\mathrm{Li}$, and lowers of alcohol in weight/reduced dry extract, tartaric acid, methanol and Fe. Those from Neossolo 2, by high values of density, $\mathrm{pH}$, ashes, alkalinity of ashes, lactic acid, 1-propanol, 2-methyl-1-propanol, amyl alcohols, $\mathrm{K}$ and $\mathrm{P}$, but lowers of OD 520; those from Argissolo 2, by high values of alcohol in weight/dry extract ratio, ethyl acetate and $\mathrm{Ca}$, and lowers hue and $\mathrm{Rb}$.

\subsection{Soil and wine phenolic compounds and antioxidant activity}

Results of the 2012 vintage show that the Principal Component Analysis discriminated wines where the three principal components (PCs) represented $95.01 \%$ of the total variation. PC 1 discriminated wine from the Argissolo 2 , which was represented by higher values of absorbance 420,520 and $620 \mathrm{~nm}$, color intensity, total polyphenols index, anthocyanins and antioxidant activity, and lower hue. PC 2 discriminated wines from Neossolo 1 and Neossolo 2, which were characterized by lower values of malvidin, resveratrol, kaempferol and quercetin, but higher tannins. PC 3 discriminated wine from Argissolo 1 , which was represented by higher values of myricetin. These results show that the soil has effect on the phenolic composition of the Merlot wine. Hence, it can have influence on its composition, quality, sensory characteristics and typicality $[12,13]$.

\section{Conclusion}

In general, the soils have different morphological and physicochemical characteristics, either in small areas. These differences may affect grapevine physiology, such as plant vigor and yield, which may reflect on grape composition and, consequently, on wine composition, quality and typicality. 
Findings of this research project show that a small vineyard of 2.42 ha has three taxonomic classes of soils, i.e., Argissolo, Cambissolo and Neossolo, and ten mapping units, each one presenting specific characteristics. In addition, partial results show that there is effect of these soils on grape and wine composition. However, these results refer to only one vintage, where temporal variability is not considered. So, the final effect of each mapping unit on grape and wine composition and quality should be known after the results of analyses of all variables, what should be done using specific statistical procedures.

The results achieved up to now may support the hypothesis that different soil characteristics, derived from their morphological and physicochemical properties, may affect wine composition and, for instance, wine quality. In addition, precision viticulture technics can be applied to small vineyard areas and may allow grape and wine producers to direct their production to a specific type of wine.

\section{References}

[1] E. Plant, G.S. Pettygrove, W.R. Reinert. Cal. Agric., 54, p.66-71 (2000)

[2] R.L. Wample, L. Mills, J.R. Davenport. ICPA, 4, p.897-905 (1999)
[3] R.G.V. Bramley, A.P.B. Proffitt. Aust. New Zeal. Grap. Winem., 427, p.11-16 (1999)

[4] C.A. Flores, J.M. Filippini Alba, H.F. Levien, D.H. Zarnott, A. Miele, C. Pavan. CBCS, 33 (2011)

[5] J.M. Filippini Alba, C.A. Flores, A. Miele, L.M. Villani. Agricultura de precisão: resultados de um novo olhar. p.370-375 (Embrapa, São Carlos, 2014)

[6] J.M. Filippini Alba, A. Miele, C.A. Flores, C. Pavan, M. Fochesato, E. Levien, H.D. Zarnott. Agricultura de precisão: um novo olhar. p.277-281 (Embrapa, São Carlos, 2011)

[7] A. Miele, C.A. Flores, J.M. Filippini Alba. Agricultura de precisão: um novo olhar. p.267-272 (Embrapa, São Carlos, 2011)

[8] J.M. Filippini, C.A. Flores, A. Miele. Rev. Bras. Vitic. Enol., 4, p.8-17 (2012)

[9] J.M. Filippini, C.A. Flores, A. Miele. ConBAP, 5 (2012)

[10] A. Miele, C.A. Flores, J.M. Filippini Alba. ICPA, 11 (2012)

[11] A. Miele, C.A. Flores, J.M. Filippini Alba. Agricultura de precisão:resultados de um novo olhar. p. 363-369 (Embrapa, São Carlos, 2014)

[12] A. Miele, C.A. Flores, J.M. Filippini Alba, C.B. Badalotti. Rev. Bras. Vitic. Enol., 6, p.40-47 (2014)

[13] A. Miele, C.A. Flores, J.M. Filippini Alba. IUFoST, 17 (2014) 